\title{
EFFECT OF CHEMICAL AND PHYSICAL VARIABLES IN THE PHOTO-ELECTROCHEMICAL REMOVAL OF ESTRIOL (E3) AND 17 a-ETHINYLESTRADIOL (EE2) IN AQUEOUS SOLUTION
}

\author{
NAYSA DÍAZ', MÓNICA PÉREZ-RIVERA ${ }^{2}$, ROSARIO CASTILLO ${ }^{3}$, RODOLFO MUNDACA ${ }^{3}$, FELIPE ARAVENA ${ }^{1}$, \\ MARIO ARANDA ${ }^{3}$, CARLOS PEÑA-FARFAL ${ }^{1 *}$ \\ ${ }^{1}$ Department of Analytical and Inorganic Chemistry, Facultad de Ciencias Químicas, Universidad de Concepción, \\ Edmundo Larenas 129, 4070043 Concepción, Chile \\ ${ }^{2}$ Department of Polymers, Facultad de Ciencias Químicas, Universidad de Concepción, Edmundo Larenas 129, 4070043 Concepción, Chile. \\ ${ }^{3}$ Faculty of Pharmacy, Universidad de Concepción, Edmundo Larenas 129, 4070043 Concepción, Chile.
}

\begin{abstract}
The effect of different variables in the electrochemical removal of estriol (E3) in aqueous solution was studied and it was compared with the removal of 17 $\alpha$ - Ethinylestradiol. The photoelectroxidations were carried out with DSA electrode $\left(\mathrm{Ti} / \mathrm{RuO}_{2}\right)$, varying the $\mathrm{pH}$, substrate concentration and supporting electrolyte, potential configuration of saline bridge, reactor volume, and light source. Results for both Estriol and $17 \alpha$ - Ethinylestradiol are similar, showing to be the best removals at concentrations of $500 \mathrm{ug} / \mathrm{L}$ of substrate, volumes to be treated of $90 \mathrm{ml}$ of solution, saline bridge of $30 \mathrm{~cm}$ in length, voltages between 0.8 and 3 , concentration of $\mathrm{Na}_{2} \mathrm{SO}_{4}$ of $0.1 \mathrm{M}, \mathrm{pH}$ between 6 and10, and UV lamp of $125 \mathrm{~W}$.
\end{abstract}

Keywords: Photoelectroxidationn, Estriol, Ethynilestradiol, endocrine disruptor, DSA (Ti/RUO $\left.{ }_{2}\right)$

\section{INTRODUCTION}

In recent decades, the interest in studying the so-called emerging pollutants has increased, as they are compounds that are used in large quantities by the population. Moreover, many of them have not been regulated in their maximum or minimum amount allowed in the environment and it is known that they return to the natural water systems, often without being treated by wastewater treatments, causing adverse effects in organisms [1]. This occurs even at very low concentrations, including $n g \mathrm{~L}^{-1}[2]$. The effect mostly reported in different works is the known "endocrine disruptor effect". The environment association defines an endocrine disruptor as an exogenous agent the interferes with synthesis, secretion, transport, union, action or elimination of natura hormones, which are responsible of maintaining homeostasis, reproduction, development and or behavior [3].

Because of the aforementioned problems is that the exhaustive study of data of environmental monitoring, transport, transformation and incidence on health has allowed focusing the study on the improvement and creation of new water treatments. Among these treatments, the "treatments of Advanced Oxidation" can be found. These are based on physicochemical processes capable to produce deep changes in the chemical structure of pollutants, which involve the generation and use of transitory powerful species such as the hydroxyl radical [4]. This radical can be generated by photochemical processes or by other forms of energy [5] and it has high effectiveness for oxidizing organic matter [6].

In the present study, photoelectroxidation techniques are used to remove Estriol and $\alpha$-Etthynilestradiol, 2 steroidal hormones. The first of them is a hormone of natural origin present mainly during pregnancy and the second one is a synthetic hormone used in oral contraceptives [7]. Both have been reported in natural and wastewaters [8] and there is evidence of their potential effect [9].

In the environment, these two hormones can be partially degraded by direct photolysis (absorption of the photoactive phenolic group) or indirectly (absorption of light by photosensitizing species such as nitrates or dissolved organic matter, which generate reactive oxygenated radicals). Sometimes, this depends on many factors, including climatic, which are often unpredictable.

Therefore, at the laboratory scale, various studies focused on removing hormones with physical, biological and chemical techniques have been developed, many times with promising results.

This work is aimed to know different variables both physical and chemical that could iaffect the photoelectrochemical removal of these hormones in aqueous solution, taking into account that this is a viable and efficient alternative that will allow decreasing removal times compared to the traditional electroxidation. In this photoelectrochemical removal by using an external light source, an additional flow of electrons is generated, decreasing the activation energy for transfer of charge through a semiconductor/electrolyte interface, obtaining a lower energy dissipation and the recovery of the maximum electrical or chemical energy [10].
In addition to the intrinsic advantage of using light, we will study different variables both physical and chemical that could influence in the removal of pollutants in aqueous solution, in order to apply the technique optimally.

\section{MATERIALS AND METHODS}

The molecular structure of the hormones under study is shown in Figure 1: Estriol (E3) and $17 \alpha$-Ethynilestradiol (EE2). Both differ from each other in the amount of $\mathrm{OH}$ present in each of them; in addition to the ethynil group present EE2.

Both EE2 and EE3 were obtained from Sigma Aldrich, with a purity > than $97 \%$. The working solutions were obtained from patterns of $5.6 \mathrm{mg} \mathrm{L}^{-1}$ of Estriol and $1 \mathrm{mg} \mathrm{L}^{-1}$ of $17 \alpha$ Ethynilestradiol, dissolved in ultrapure water, and filtered with PVDF filters $(0.45 \mu \mathrm{m}$, Whatman).

In order to study the effect of concentration of the analyte on the degradation rate, there were three concentration levels: 500, 700 and 1,000 $\mu \mathrm{g} \mathrm{L}^{-1}$ of hormones, keeping three concentration of $\mathrm{Na}_{2} \mathrm{SO}_{4}(0.1 \mathrm{M})$ constant, whereas when performing the $\mathrm{Na}_{2} \mathrm{SO}$ concentration variation experiments $(0.1$ $-0.3-0.5 \mathrm{M})$, the concentration of hormone was kept constant $\left(500 \mu \mathrm{g} \mathrm{L}^{-1}\right)$. Experiments of different light sources ( $260 \mathrm{~W}$ mixed lamp, $125 \mathrm{~W}$ mercury lamp, 20W UV lamp, and 125 W UV-C Philips lamp), saline bridge length (20$30 \mathrm{~cm})$, solution volume to be treated $(90-250 \mathrm{ml}), \mathrm{pH}(3-6-10)$ and Potential (0.8-6-10 V) were performed at $500 \mu \mathrm{g} \mathrm{L}^{-1}$ of hormone and $0.1 \mathrm{M} \mathrm{de} \mathrm{Na}_{2} \mathrm{SO}_{4}$.

The dimensionally stable electrode (DSA) $\left(\mathrm{Ti} / \mathrm{RuO}_{2}\right)$ was obtained from the cooperation of an academic of the Department of Chemical Engineering. In the experimental studies an electrode measured $16 \mathrm{~cm}^{2}$ total surface with a thickness of $0.1 \mathrm{~mm}$ was used. The saline bridge was built with a U-shaped glass tube $(0.5 \mathrm{~mm} \varnothing)$, filled with a $4 \mathrm{M} \mathrm{KNO}_{3}$ solution (Merck), gelled in $1 \%$ agarose

\subsection{Electrochemical measurements and photoxidations}

Pulse voltammetry and cyclical voltammetry (scanning rate $=0.1 \mathrm{~V} / \mathrm{s}$ ) was performed in order to observe the electrochemical performance of the hormones in the scanning range of 0 to $1 \mathrm{~V}$, whereas for photoelectroxidations of the solutions, the bulk electrolysis modality with coulometry was used. The equipment used was an Electrochemical Analyzer ( $\mathrm{HCH}$ Instruments), using the $\mathrm{CHI} 821 \mathrm{C}$ software, connected to a computer. The working electrodes were dimensionally stable electrode $\left(16 \mathrm{~cm}^{2}\right.$ area, $0.1 \mathrm{~mm}$ thickness $)$ against stainless steel electrode and $\mathrm{Ag} / \mathrm{AgCl}$ electrode as counter and reference electrode, respectively, because potentiostatic oxidation was used. 
A)

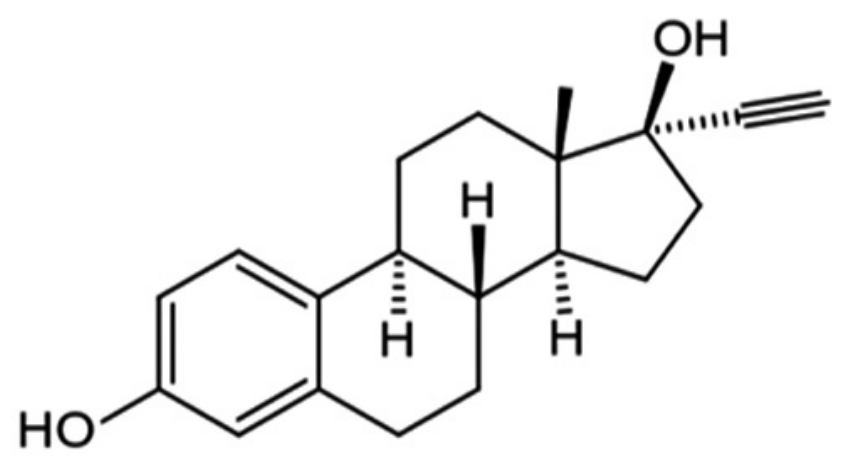

B)

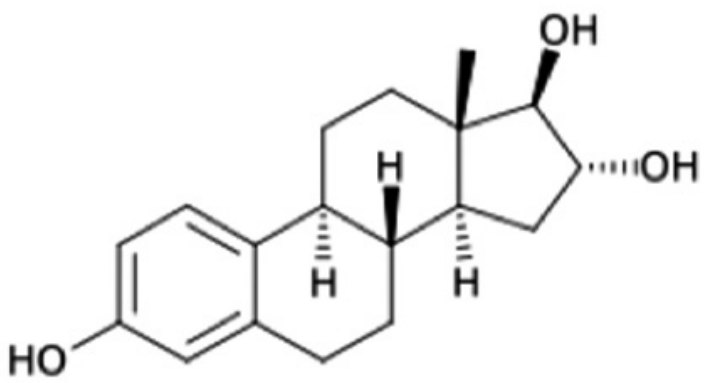

Figure 1: Chemical structure of $17 \alpha$-Ethynilestradiol (A) and Estriol (B).

All phoelectroxidations were performed in divided cells, whose content was continuously stirred with magnetic stirrer. The anode was illuminated with different light sources (mixed lamp. $20 \mathrm{~W} \mathrm{UV}, 125 \mathrm{~W} \mathrm{UV}$ ) at a distance of $8 \mathrm{~cm}$ from the anode. This is different from the classic oxidation cells in which a single two-electrode cell is used (anode and cathode without reference electrode). This configuration was preferred to avoid the appearance of parasitic reactions in the cathode.

Anode and cathode were separated by a saline bridge (glass tube $4 \mathrm{M}$ gelled $\mathrm{KNO}_{3}$ ). After each experiment, electrodes were washed with acetone/water (50 $-50 \% \mathrm{v} / \mathrm{v})$ and electrolyzed with diluted $\mathrm{H}_{2} \mathrm{~S} 0{ }_{4}(0.5 \mathrm{M})$ for 5 minutes and then rinsed with abundant Milli Q water. Samples were taken every 5 minutes, which were filtered and injected in high resolution liquid chromatographer (HPLC).

2.2 Analysis of Estriol and $17 \alpha$ Ethynilestradiol by high resolution chromatography (HPLC)

Concentrations of E3 and EE2 were measured by HPLC (YL Clarity 9100). Separations were performed in an RP-C 8 column (125 mm X $4.6 \mathrm{~mm}$, particle

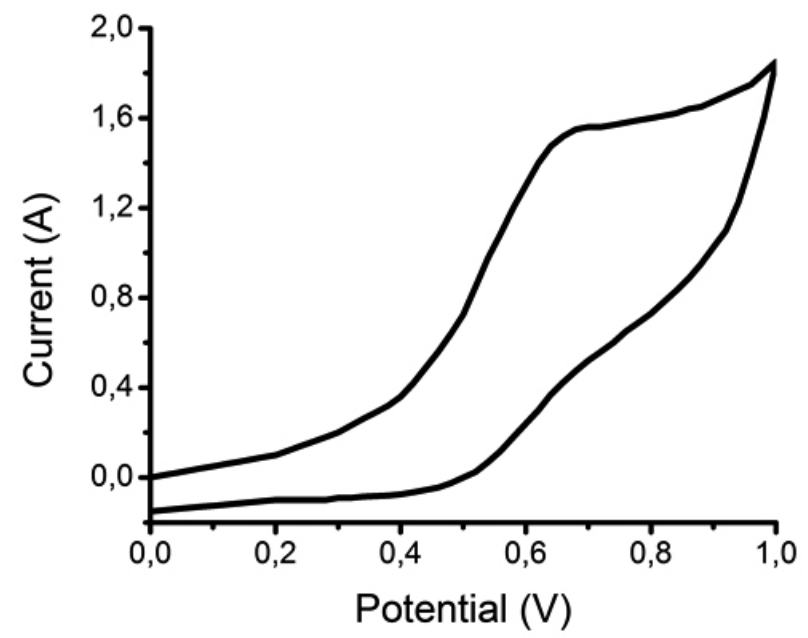

size, $5 \mu \mathrm{m})$. On the other hand, the mobile phase was acetonitrile / water (50:50 $\mathrm{v} / \mathrm{v}$ ) at a flow of $1 \mathrm{~mL} \mathrm{~min}{ }^{-1}$. The injection volume was $20 \mu \mathrm{L}$ and the working wavelength for the quantitative analysis was $200 \mathrm{~nm}$. Retention time of E3 was $2.05 \mathrm{~min}$ and for EE2 was $5.71 \mathrm{~min}$. The relative standard deviations (RSD) ranged from 0.92 and $3.93 \%$ for E3 and 0.46 to 7.8 for EE2, in the range of concentrations between 20 and $1,000 \mu \mathrm{g} \mathrm{L}^{-1}$. The linear adjustment of the calibration curve was $\mathrm{R}^{2}>0.99$.

\section{RESULTS AND DISCUSSION}

3.1 Pulse and cyclic voltammetry

Pulse and cyclic voltammetry $(0-1 \mathrm{~V})$, of $200 \mathrm{mg} \mathrm{L}^{-1}$ for E3 and EE2 in $0.1 \mathrm{M} \mathrm{Na}_{2} \mathrm{SO}_{4}$, shows a defined oxidation peak around 0.62 and $0.68 \mathrm{~V}$ against $\mathrm{Ag} / \mathrm{AgCl}^{2}$ (Fig. 2). In inverse exploration $1-0 \mathrm{~V}$ no peak corresponding to the reduction is observed. This suggests that the electrochemical oxidation of E3 and $\mathrm{EE} 2$ in $\mathrm{Ti} / \mathrm{RuO}$ is totally irreversible.

Figure 2: Cyclic (A) and pulse (B) voltamperogram of $200 \mathrm{mg} \mathrm{L}^{-1} \mathrm{E} 3,0.1 \mathrm{M} \mathrm{Na}_{2} \mathrm{SO}_{4}$.

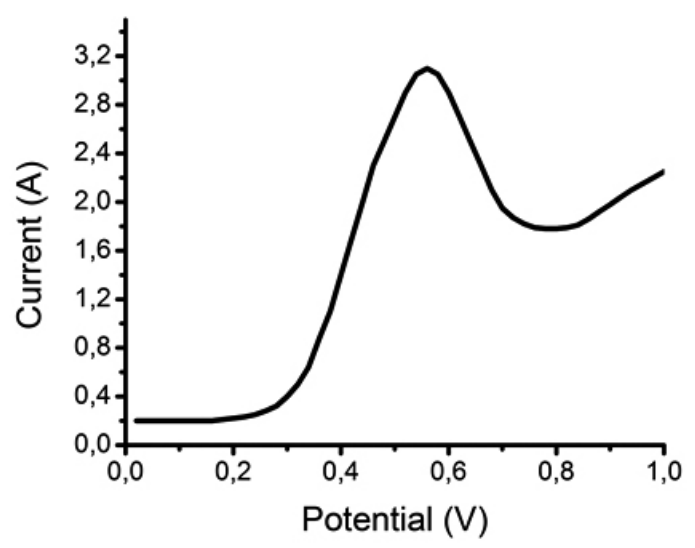

\subsection{Effect of Light source}

In this experience, the removal efficiency of $500 \mu \mathrm{g} \mathrm{L}^{-1}$ of hormones, with and without exposition to different sources of artificial lights was compared. As can be observed in Figure 3, in the experiments performed in absence of light (electrolysis), removals of $40 \%$ for E3 and 25\% for EE2 were obtained at 120 min of reaction $\left(0.8 \mathrm{~V}, 0.1 \mathrm{M} \mathrm{Na}_{2} \mathrm{~S}_{4}, \mathrm{pH}\right.$ ), with degradation rates 6-7 times lower for E3 and EE2 at 90 min reaction, respect to experiments performed with $125 \mathrm{~W}$ ultraviolet radiation. In the latter conditions, higher removals up to $100 \%$ for E3 and $92 \%$ for EE2 can be obtained after 120 min of reaction (125
W UV-lamp) (Figure 3). When comparing artificial light sources, differences are also evidenced. By using lamps the emit in the visible light spectrum (mixed lamps), radiations 3-4 times higher for E3 and EE2 are obtained after 60 min of reaction, respect to the $125 \mathrm{~W}$ UV light source. Finally, if UV Light sources with different power are compared, it will be evidence that the speed of the reactions will be favored at higher powers, this due to the higher number of target photons/molecules.

The degradation of hormones in water under different experimental conditions have been studied in several works and in general, the photolysis 
achieves degradations in the range of $1-35 \%$ for EE2. Results will depend on the type of matrix, power of the light source, and the concentration of the compound, as well as the intrinsic properties such as its molar extinction coefficient and its quantum performance [11], though in general the removals are insignificant.

In river water, the average lifetime of EE2 is at least 10 days, with daily exposures of 12 hours at sunlight. However, this type of natural system where no control of all variables can not be maintained, degradation is limited for instance, by the turbidity of the water and attenuation of light in the depths, among other variables [12]. Better results have been reported in other works in the degradation of endocrine disrupting compounds, but when combined with Iron, $\mathrm{H}_{2} \mathrm{O}_{2}, \mathrm{TiO}_{2}, \mathrm{O}_{3}$ among others. Thus, the removal $\%$ of BPA can be increased from $60 \%$ through photolysis until $100 \%$ at $60 \mathrm{~min}$ with selforganized matrix nanotubular TIO, electrodes, using a $125 \mathrm{~W}$ mercury lamp, $1.5 \mathrm{~V}$ at $\mathrm{pH} 6[13]$.
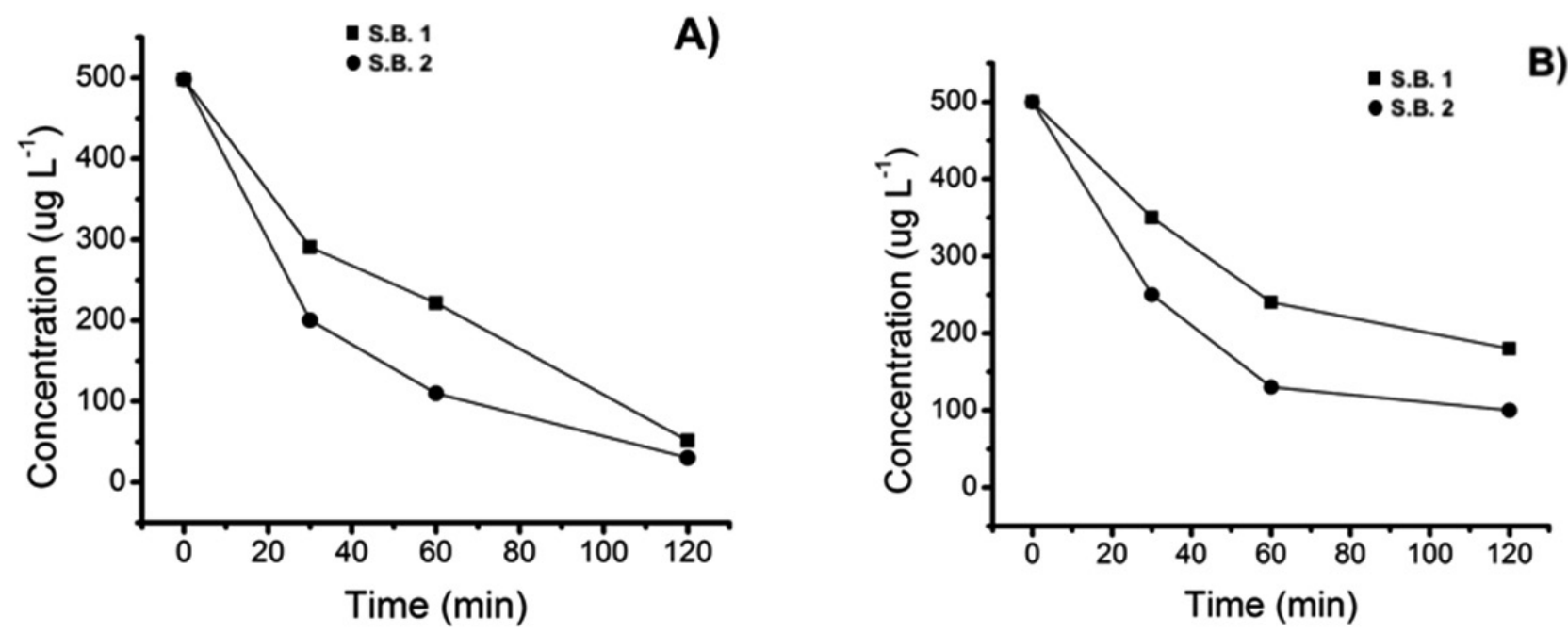

Figure 3: Effect of Light on the degradation of $500 \mu \mathrm{g} \mathrm{L}^{-1}$ de $\mathrm{E} 3$ (A) and EE2 (B), $0.1 \mathrm{M} \mathrm{Na}_{2} \mathrm{SO}_{4}, \mathrm{pH} 6,0.8 \mathrm{~V}$,

3.3. Saline bridge configuration effect and solution volume

When performing experiments varying the solution volume and keeping constant the concentration of hormone $\left(500 \mu \mathrm{g} \mathrm{L}^{-1}\right)$, supporting electrolyte $(0,1 \mathrm{M})$ at a voltage of $0.8 \mathrm{~V}$, an increase in the removal at a volume of $90 \mathrm{~mL}$ can be observed (Fig. 3 ). This can be due to the shorter path of the analyte to the electrode, in comparison to the distance between what the analyte must travel in a larger size reactor.

When the reactor is $90 \mathrm{~mL}$, high removals of the species under study are obtained especially in the first minutes of reaction, which would indicate that the removal is a first-order reaction. Another factor to be considered is that the electrode is the same for both cases, having the same contact surface but for a larger volume. These results $(250 \mathrm{~mL})$ could be improved by increasing the size of the electrode, proportionally to the increase in volume.

Regarding the configuration of the saline bridge, a greater longitude favors removals, since there is more $\mathrm{KNO}_{3}$ being driven through it $[12,14,15]$.
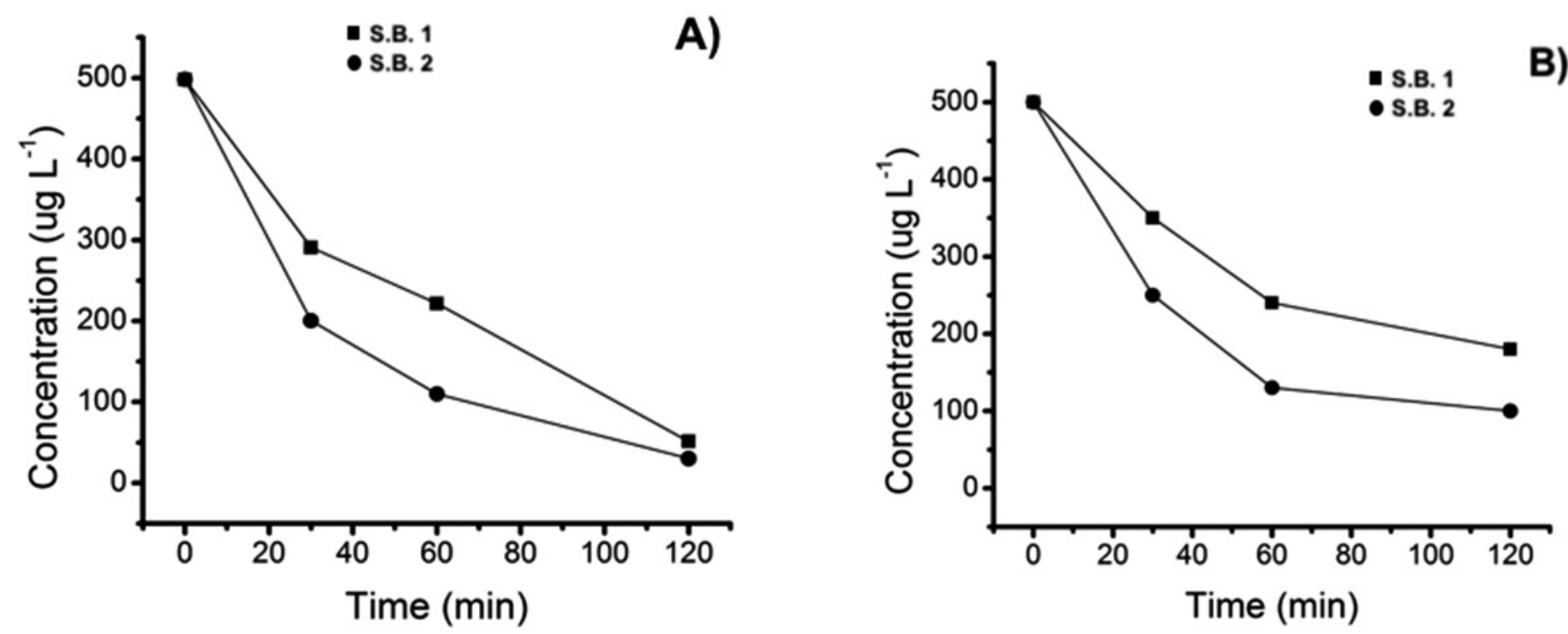

Figure 4: Effect of saline bridge length (A) on the removal of $500 \mu \mathrm{g} \mathrm{L}^{-1}$ of E3 (A) and EE2 (B) at $0.8 \mathrm{~V}, 0.1 \mathrm{M} \mathrm{of} \mathrm{Na}_{2} \mathrm{SO}_{4}$, pH 6. 

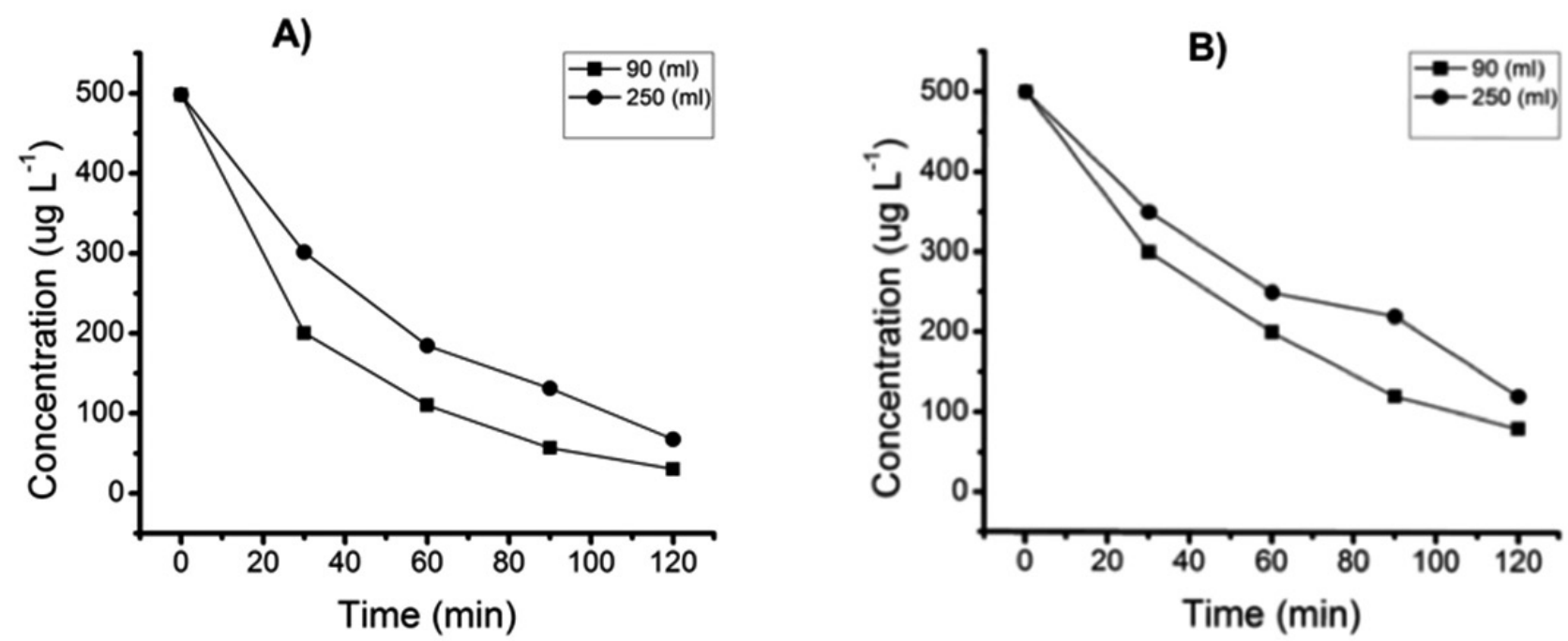

Figure 5: Effect of the volume of the solution to be treated in the removal of $500 \mu \mathrm{g} \mathrm{L}^{-1} \mathrm{de} \mathrm{E} 3(\mathrm{~A})$ and EE2 (B) a $0,8 \mathrm{~V}, 0,1 \mathrm{M}$ of $\mathrm{Na}_{2} \mathrm{SO}{ }_{4}, \mathrm{pH}^{6}$.

3.4. Effect of the supporting electrolyte concentration

When carrying out the experiences of hormone removal $\left(500 \mu \mathrm{g} \mathrm{L}^{-1}\right), 0.8$ $\mathrm{V}$, at different concentrations of $\mathrm{Na}_{2} \mathrm{SO}_{4}$, removals higher than concentrations of $0.1 \mathrm{M}$ are obtained, as well as a significant decrease, for instance at $0.5 \mathrm{M}$ de $\mathrm{Na}_{2} \mathrm{SO}_{4}$. This suggests that at these concentrations the work is being performed with an excess of electrolyte, which causes an increase in the viscosity of the medium and hence, a lower transport of analyte to the electrode and a lower removal. In the work by Brugnera [13], the effect of the supporting electrolyte is also studied, but at lower concentrations. Thus, a maximum of mineralization at concentrations of $0.1 \mathrm{M}$ are obtained.
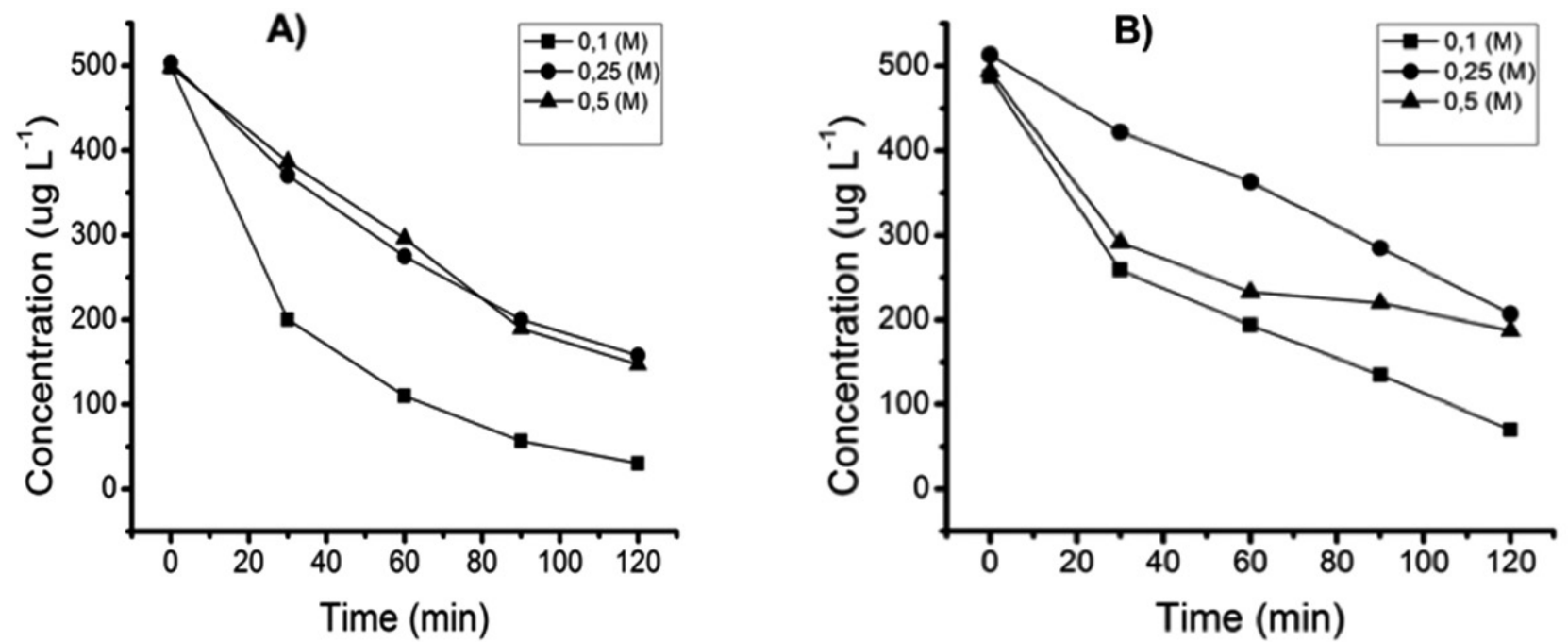

Figure 6. Effect of the variation of concentration of the supporting electrolyte $\left(\mathrm{Na}_{2} \mathrm{SO}_{4}\right)$ in the removal of $500 \mu \mathrm{g} \mathrm{L}-1$ of E3 (A) and EE2 (B) at $0.8 \mathrm{~V}$, pH 6.

\subsection{Effect of $\mathrm{pH}$ variation}

Removal of hormones is directly affected by $\mathrm{pH}$. Thus, it can be observed in Figure 7 that as $\mathrm{pH}$ increases, removals also do so. The above is explained by observing the chemical structures of hormones (Figure 1), which are weak acids, with a $\mathrm{pKa}>10$. This indicates that they are fully ionized at a $\mathrm{pH}>10$, leaving the structure negatively charged and it will facilitate the displacement to the anode (positively charged) where the removal takes place.

On the other hand, the isoelectric point of $\mathrm{RuO}_{2}$ is found at $\mathrm{pH} 6.5$, which indicated that E3 and EE2 are preferentially absorbed when the surface of $\mathrm{RuO}_{2}$ is in the charged form [16]. 

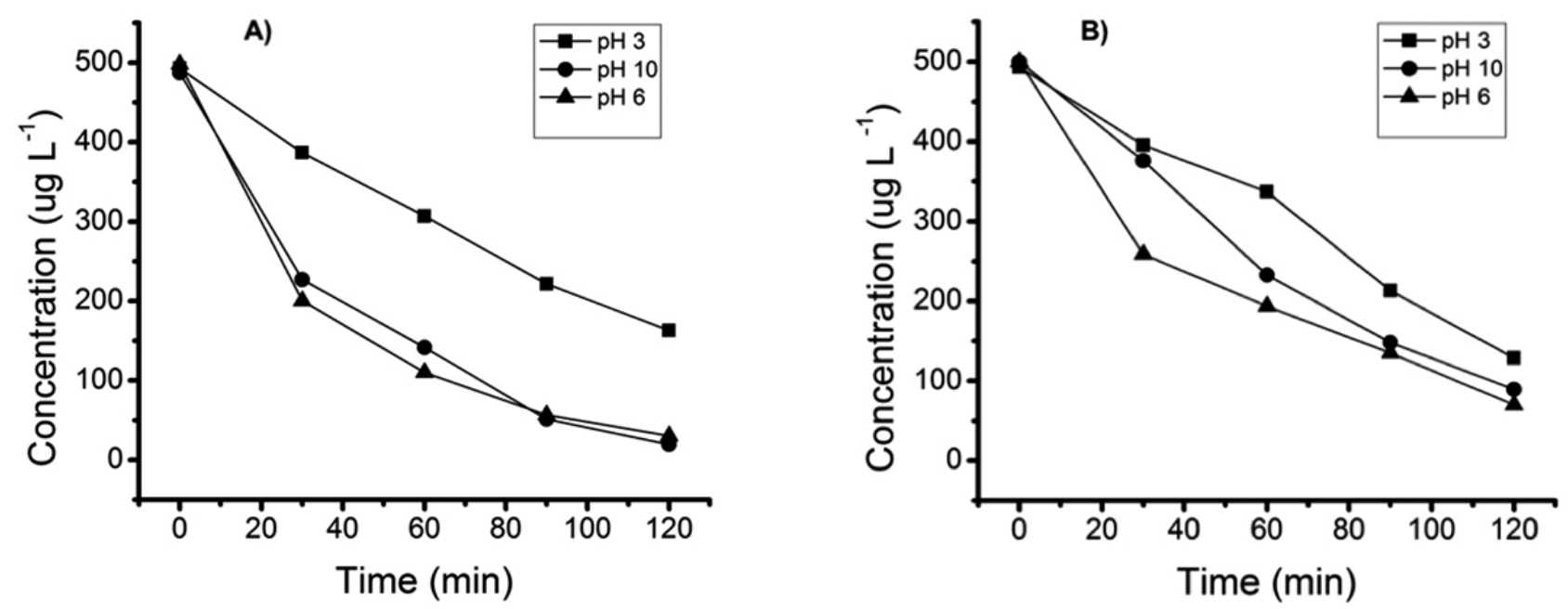

Figure 7: Effect of $\mathrm{pH}$ variation on the removal of $500 \mu \mathrm{g} \mathrm{L}-1$ of E3 (A) and EE2 (B) at $0.8 \mathrm{~V}$ and $0.1 \mathrm{M} \mathrm{Na}_{2} \mathrm{SO}_{4}$.

\subsection{Effect of variation in potential}

By varying the potential applied to the photoelectrochemical removal of E3 and EE2 it can be observed that the best removal potentials are found at a potential of $0.8 \mathrm{~V}$ compared to higher voltages. This can be attributed to the predominance of collateral parasitic reactions, such as the reaction of evolution of oxygen. This trend can be observed in other studies such as that by Nájera [17], where they refer to the influence of of the density of the applied current on the removal efficiency of a GES-EE2 mixture. In this study, three levels of densities of current of 16,32 and $48 \mathrm{~mA} \mathrm{~cm}^{2}$ were tested. As shown here, in some cases as the density of current increases $\left.(48 \mathrm{~mA} \mathrm{~cm})^{2}\right)$, a limit value will be reached, where the reaction stabilizes. In other cases, there is a decrease in the efficiency of the anodic oxidation, so the density of the current and voltage is not capable to control the efficiency of the oxidative system.

On the other hand, although the potential applied is low, it is still more positive than the flat band potential, so there is a potential gradient on the film of ruthenium oxide, which will result in an electric field that keeps the photogenerated charges. Therefore, the adsorption of E3 and EE2 and/or the generation and separation of electron-hole pairs that are accelerated under this gradient will be favored. Thus, a quick decomposition is promoted [18] (Rajeshwar and Ibanez 1997).
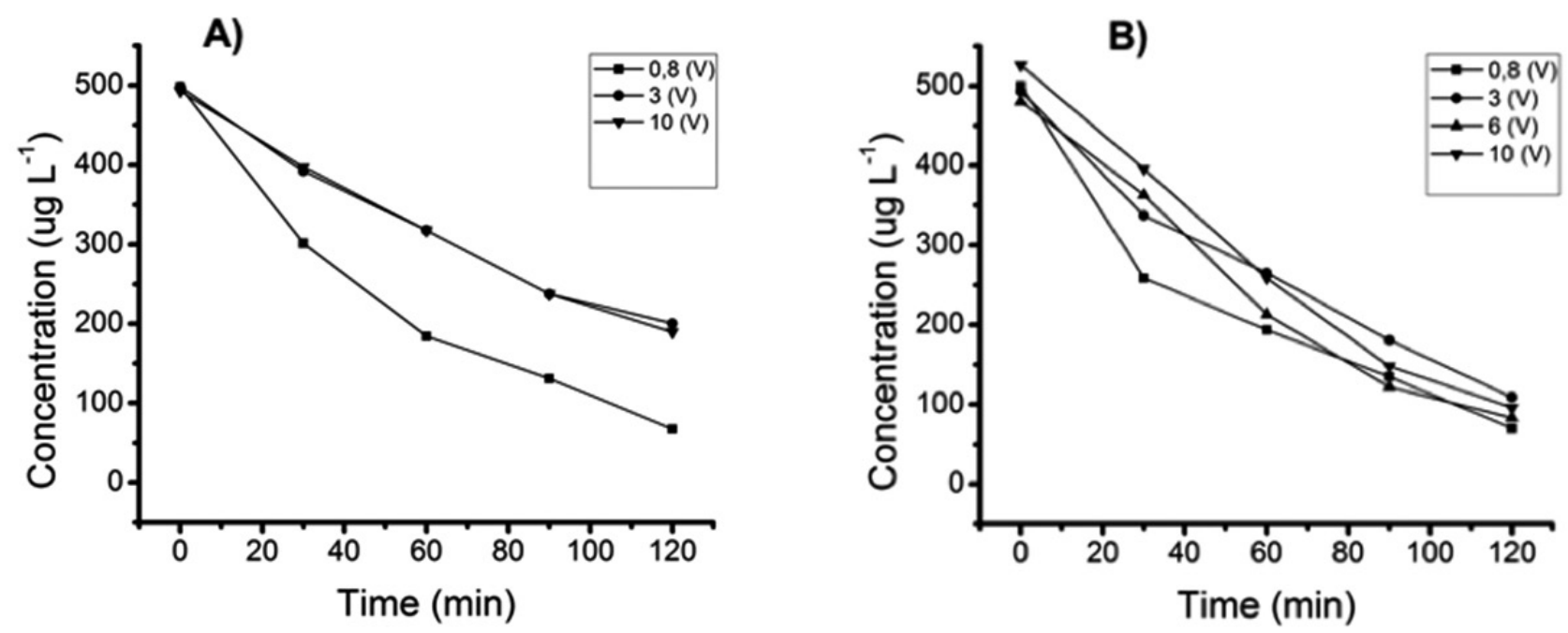

Figure 8: Effect of variation of potential on the removal of $500 \mu \mathrm{g} \mathrm{L}^{-1}$ of E3 (A) and EE2 (B), $0.1 \mathrm{M} \mathrm{Na}_{2} \mathrm{SO}_{4}$, at pH 6

3.6. Effect of substrate variation concentration

A total of three concentrations of E3 and EE2 $\left(500,750,1000 \mu \mathrm{g} \mathrm{L}^{-1}\right)$ were studies to observe the effect of concentration on the removal on the surface of the $\mathrm{Ti} / \mathrm{RuO}$, electrode.. Figure 9 shows concentration removal with the decrease of the initial concentration. Thus, it is observed in Fig. 9 A that the removal at $30 \mathrm{~min}$ is five times higher when working at concentration $500 \mu \mathrm{g} \mathrm{L}^{-1}$ than 1000 $\mu \mathrm{g} \mathrm{L}{ }^{-1}$, and double removal of concentration at $120 \mathrm{~min}$ of reaction.

For EE2 (Figure 9B) as well as estriol, removals are favored at lower initial concentration, doubling at $120 \mathrm{~min}$ of reaction at $500 \mu \mathrm{g} \mathrm{L}^{-1}$ compared to 1,000 $\mu \mathrm{g} \mathrm{L}^{-1}$. It is known that an increase in the initial concentration of a compound increases its concentration gradient and the mass transference through the diffusion layer and therefore, its degradation in the electrode. However, many times the electrode is saturated at high concentrations of the analyte [10] or the electrogenerated hydroxyl radicals are depleted due to competitive reaction for the $\mathrm{OH}$ radical. This leads to a parallel consumption of it, for example the oxidation of many compounds (intermediates) with $\mathrm{OH}[19]$.

On the other hand, the degradation profile follows the performance firstorder kinetics, where reaction rates depend on the concentration as concentration increases ( 500 to $1,000 \mu \mathrm{g} \mathrm{L}^{-1}$ ) and the degradation rate decreases. This leads to a decrease in the kinetic coefficient of 0.023 to $0.006 \mathrm{~min}^{-1}$ for E3 and 0.016 to $0.006 \mathrm{~min}^{-1}$ for EE2. 

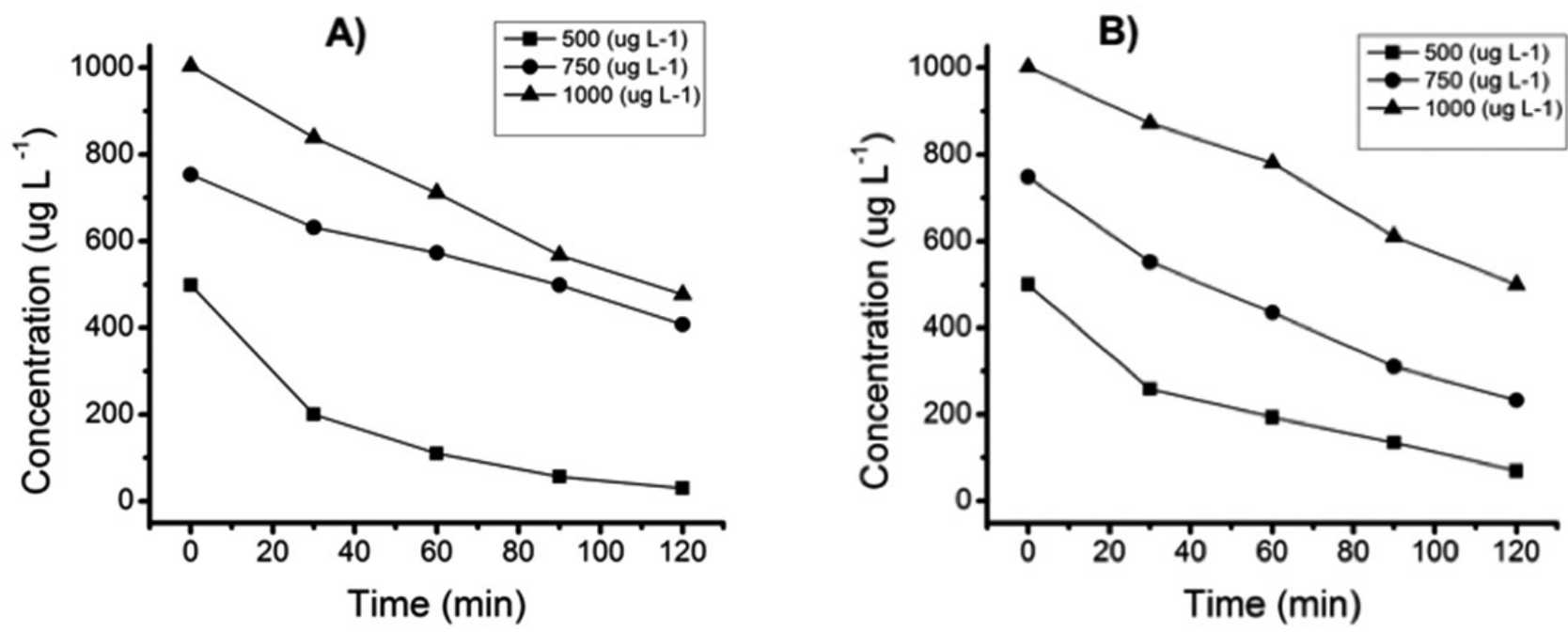

Figure 9: Effect of the concentration variation of E3 (A) and EE2 (B) at $0.8 \mathrm{~V}, 0.1 \mathrm{M} \mathrm{Na}_{2} \mathrm{SO}_{4}$ at pH 6.

\section{CONCLUSIONS}

There are different variables that affect the renoval of E3 and EE2. Thus, it can be concluded that a greater length of the saline bridge $(30 \mathrm{~cm})$ and smaller volume of solution $(900 \mathrm{ml})$ favor the removals of hormones, especially during the first $30 \mathrm{~min}$ of reaction. In turn, the source light has direct implications on the efficiency of percentages of removal, as well as the light source with $125 \mathrm{~W}$ of power. This allows us to obtain removals greater than $90 \%$, at a potential of $0.8 \mathrm{~V}, 500 \mu \mathrm{g} \mathrm{L}-1$ de hormone, natural $\mathrm{pH}$ and $0.1 \mathrm{M}^{-} \mathrm{Na}_{2} \mathrm{SO}_{4}$.

On the other hand, the effect of concentration of the supporting electrolyte allows concluding that $0.1 \mathrm{M}$ concentration of $\mathrm{Na}_{2} \mathrm{SO}_{4}$ is more effective than higher salt concentrations. The $\mathrm{pH}$ is also a significant factor, since at higher $\mathrm{pH}$; removals also increase, favoring the transport of the analyte to the anode (see discussion).

Regarding the effect of the potential, lower potentials $(0.8 \mathrm{~V})$ present better efficiencies in the percentages of removal (30\% higher at $120 \mathrm{~min}$ of reaction) respect to $3 \mathrm{~V}$ and $10 \mathrm{~V}$. However, no significant differences are observed for EE2 at 120 min when using potentials of $0.8-6-1 \mathrm{~V}$. This concludes that $0.8 \mathrm{~V}$ is more efficient, also due to an economic factor.

Finally, concentrations of $500 \mu \mathrm{g} \mathrm{L}-1$ allow obtaining removals of Estriol five times higher than for $1000 \mu \mathrm{g} \mathrm{L}^{-1}$ and double removal for EE2 at $120 \mathrm{~min}$ of reaction.

\section{AKNOWLEDGMENS}

The authors are grateful for the financial support provided by FONDECYT 1120815 VRID 216.024.039.

215.071.063. Naysa Díaz thanks CONICYT for Doctoral Grant and Thesis in the Industry Project 781412007

\section{REFERENCES}

[1] L.G. Parks, C.S. Lambright, E.F. Orlando, L.J. Guillette, G.T. Ankley, L.E. Gray. Masculinization of female mosquitofish in kraft mill effluentcontaminated Fenholloway River water is associated with androgen receptor agonist activity. Toxicological Sciences. (2001) 62 (2), pp. 257267.

[2] L. Clouzot, M. Benoit, D. Pierre, N. Roche. (2008). 17 $\alpha$-Ethinylestradiol: An endocrine disrupter of great concern. Analytical methods and removal processes applied to water purification. A review. Environmental Progress \& Sustainable Energy. (2008) 27 (3), pp. 383-396.

[3] R. J. Kavlock, G. P. Daston, C. De Rosa, P. Fenner-Crisp, L. E. Gray, S. Kaattari, G. Lucier, M. Luster, M. J. Mac, C. Maczka. Research needs for the risk assessment of health and environmental effects of endocrine disruptors: A report of the U.S. Environ. Health Perspect. (1996) 104 (Suppl. 4), pp. 715-740.

[4] C.P. Huang, C. Dong, Z Tang. Advanced chemical oxidation: its present role and potential future in hazardous waste treatment. Waste management.
(1993) 13, pp. 361-377.

[5] X. Domenech, W. F. Jardim, M. I. Litter. "Eliminación de contaminantes por fotocatálisis heterogénea”, Miguel A. Blesa (Ed.), Procesos avanzados de oxidación para la eliminación de contaminantes, Red Cydted VIII, Buenos Aires, (2001), pp. 3-26

[6] M. Klavarioti, D. Mantzavinos, D. Kassinos. Removal of residual pharmaceuticals from aqueous systems by advanced oxidation processes. Environment international. (2009). 35 (2), pp. 402-417.

[7] Z.H. Liu, Y. Kanjo, S. Mizutani. Removal mechanisms for endocrine disrupting compounds (EDCs) in wastewater treatment-physical means, biodegradation, and chemical advanced oxidation: a review. Science of the Total Environment. (2009), 407 (2), pp. 731-748.

8] A.C. Johnson, R. Williams. A model to estimate influent and effluent concentrations of estradiol, estrone, and ethinylestradiol at sewage treatment works. Environmental science \& technology. (2004) 38 (13), pp. 3649-3658.

[9] A.Z. Aris, A. S. Shamsuddin, S.M. Praveena. Occurrence of $17 \alpha$-ethynylestradiol (EE2) in the environment and effect on exposed biota: a review. Environment international. (2014) 69, pp. 104-119.

[10] H.M. Coleman, M.I. Abdullah, B.R. Eggins, F.L. Palmer. Photocatalytic degradation of $17 \beta$-oestradiol, oestriol and $17 \alpha$-ethynyloestradiol in water monitored using fluorescence spectroscopy. Applied Catalysis B: Environmental. (2005) 55 (1), pp. 23-30.

[11] B. Cédat, C. De Brauer, H. Métivier, N. Dumont, R. Tutundjan. (2016) Are UV photolysis and $\mathrm{UV} / \mathrm{H} 2 \mathrm{O} 2$ process efficient to treat estrogens in waters Chemical and biological assessment at pilot scale. Water Research. (2016) 100 (1), pp.357-366

[12] L.A. Racz, R.K. Goel. Fate and removal of estrogens in municipal wastewater. Journal of Environmental Monitoring. (2010), 12 (1), pp. 5870.

[13] M.F. Brugnera, K. Rajeshwar, J. Cardoso, M.V.B. Zanoni. Bisphenol A removal from wastewater using self-organized TIO 2 nanotubular array electrodes. Chemosphere. (2010) 78 (5), 569-575.

[14] C. Salazar, C.A. Zaror; M.A. M.A. Mondaca, P. Gonzalez; H. Mansilla, C. Pena. Advanced Electrochemical Oxidation of Ultrafiltration Permeates from Cellulose Bleaching Effluents. Journal of Advanced Oxidation Technologies. (2012), 15 (2) pp. 254-265

[15] C.A. Zaror; C. Salazar, E.A. Araneda, M.A. Mondaca, H.D. Mansilla, C. Pena. Electrochemical Treatment of Segregated Effluents from the D-Stage in ECF Kraft Cellulose Bleaching. Journal of Advanced Oxidation Technologies. (2011), 14 (1), pp. 47-53.

[16] M.V.B. Zanoni, J.J. Sene, M.A. Anderson. Photoelectrocatalytic degradation of Remazol Brilliant Orange 3R on titanium dioxide thin-film electrodes. Journal of Photochemistry and Photobiology A: chemistry. (2003), 157 (1), pp. 55-63.

[17] H. Nájera, R. Gutiérrez, R. González, C. García, R. Méndez, M. Rojas. (2016). Degradation of gestodene (GES)-17 $\alpha$-ethinylestradiol (EE2) mixture by electrochemical oxidation. Journal of Water and Health. 
(2016), 14 (6), 980-988.

[18] K. Rajeshwar, J. Ibanez. Environmental electrochemistry: Fundamentals and applications in pollution sensors and abatement. Academic Press. (1997) Chapter 7
[19] B. Boye, E. Brillas, B. Marselli, P.A. Michaud, C. Comninellis, G. Farnia, G. Sandonà. Electrochemical incineration of chloromethylphenoxy herbicides in acid medium by anodic oxidation with boron-doped diamond electrode. Electrochimica Acta. (2006), 51 (14), pp. 2872-2880. 